DIMENSI, VOL. 8, NO. $1: 142-166$

MARET 2019

ISSN: 2085-9996

\title{
KETIMPANGAN GENDER PADA KASUS INCEST DALAM PEMBERITAAN MEDIA DALAM JARINGAN (ANALISIS WACANA BAHASA)
}

\section{GENDER INEQUALITY IN THE INCEST CASE ON ONLINE REPORT (DISCOURSE ANALYSIS)}

\author{
Nureza Dwi Anggraeni \\ (Prodi Bahasa Inggris, Fakultas Ilmu Keguruan dan Ilmu Pendidikan, Universitas Riau Kepulauan, Indonesia) \\ anggraeni.resa@gmail.com
}

\begin{abstract}
Abstrak
Pemberitaan terkait kasus ayah perkosa anak kandung (incest) di Merdeka.com mengarah pada penyudutan posisi istri yang tidak bisa melayani kebutuhan biologis suami. Efek pembaca setelah membaca suatu berita tersebut juga dipengaruhi oleh angle yang diambil oleh jurnalis atau "dipesankan” media kepada jurnalisnya. Kepentingan dalam sebuah media sangat berpengaruh dalam penulisan berita. Media mampu menggiring interpretasi pembaca, sesuai dengan keinginan penguasa media melalui bahasa yang dituliskan oleh jurnalis. Jurnalis juga ikut berperan dalam penulisan berita sebagai penyampai infomasi kepada khalayak. Kognisi sosial jurnalis terhadap suatu kasus juga ikut mempengaruhi penulisan berita. Ketimpangan posisi istri pada kasus ayah yang tega memerkosa anak kandungnya ini dianalisis berdasarkan perspektif Van Dijk, untuk mengetahui motif media Merdeka.com atau jurnalis yang menghimpun 4 teks berita dan 1 teks intro terkait alasan ayah yang tega memerkosa anak kandungnya.
\end{abstract}

Kata Kunci: Gender, Incest, Pemberitaan Media Online

\begin{abstract}
News related to the case of the incestuous father of raping at Merdeka.com led to a wife's position which could not serve her husband's biological needs. The effect of the reader after reading the news is also influenced by the angle taken by the journalist or "ordered" by the media to his journalist. Interest in a media is very influential in writing news. The media is able to lead the interpretation of the reader, in accordance with the wishes of the media ruler through the language written by journalists. Journalists also play a role in news writing as the delivery of information to the public. Journalists' social cognition of a case also influences news writing. The inequality of the wife's position in the case of a father who could rape his biological child was analyzed based on Van Dijk's perspective, to find out the media motives of Merdeka.com or journalists who collected 4 news texts and 1 intro text related to the father's reason to rap his biological child.
\end{abstract}

Kata Kunci: Gender, Incest, Pemberitaan Media Online

\section{PENDAHULUAN}

Kasus pemerkosaan yang dilakukan ayah ke anak (incest) merupakan salah satu kegiatan penyimpangan seksual. Incest memiliki pengertian hubungan seks dengan sesama anggota keluarga sendiri di luar suami istri seperti antara ayah dan anak perempuan, ibu dengan anak laki-lakinya, ataupun antara saudara kandung perempuan dengan laki-laki. Kasus 
incest ini banyak diberitakan di media dengan berbagai sudut pandang. Hal tersebut menjadi wacana yang dapat memengaruhi pembaca seperti tujuan wacana itu dibuat. Untuk melihat sejauh mana wacana berkembang dan tujuan apa yang sebenarnya ingin disampaikan para penulis berita atau jurnalis dalam pemberitaan yang dibuat, diperlukan adanya analisis wacana kritis dengan berbagai macam perspektif.

Kasus incest (ayah perkosa anak kandung) yang diproduksi oleh jurnalis terindikasi menyudutkan posisi istri dalam pemberitaan Merdeka.com. Pandangan, kepercayaan, dan prasangka yang berkembang dalam masyarakat mempengaruhi pandangan jurnalis. hal tersebut sangat bergantung pada memori, pengalaman, dan interpretasi jurnalis dalam mendefinisikan dan membentuk identitas individu termasuk realitas incest. Sebagai contoh pembentukan identitas pelaku, merdeka.com menggunakan pernyataan bejat, gila, dan sebagainya. Jadi, Van Dijk melihat bagaimana struktur sosial, dominasi, dan kelompok kekuasaan yang ada dalam masyarakat dan bagaimana kognisi atau pikiran dan kesadaran membentuk dan berpengaruh terhadap teks tertentu (van Dijk, 1997:8).

Perspektif van Dijk, juga dapat digunakan dalam memahami bagaimana media mengonstruksi realitas mengenai posisi istri dalam kasus incest (pemerkosaan yang dilakukan ayah terhadap anak kandungnya) menjadi sebuah wacana. 4 pemberitaan oleh Merdeka.com terkait kasus ayah yang tega memerkosa anak kandungnya, 3 diantaranya mengambil judul yang merugikan kaum istri karena diberitakan secara timpang. Sebagai contoh, kasus incest yang berjudul “Kalut Istri Tak Kunjung Pulang Jadi TKW” jurnalis mengungkapkan judul namun lead tidak sesuai dengan judul. Jurnalis mengambil angle istri yang menyebabkan pemerkosaan terhadap anak itu terjadi tanpa menulis hasil wawancara dengan istri tersebut. Pemberitaan Merdeka.com dalam kasus incest menggiring pembaca untuk menjustifikasi atau menyalahkan posisi istri atas kejadian pemerkosaan dalam keluarga. Pada konteks ini Merdeka.com menggunakan kognisi sosial yang dimiliki jurnalis untuk berupaya membangun realita sosial dalam masyarakat.

\section{Ayah Perkosa Anak Kandung Merupakan Perbuatan Incest}

Belakangan ini banyak sekali ditemukan seorang anak menjadi korban perkosaan yang dilakukan anggota keluarganya sendiri, terutama oleh ayah kandungnya yang lazim 
disebut incest. Incest atau inses merupakan hubungan seksual antara orang-orang yang bersaudara dekat yang dianggap melanggar adat, hukum dan agama. Incest berasal dari bahasa latin Incestus yang berarti tidak suci, tidak senonoh dan incestare yang berarti menodai atau mengotori. Definisi incest yang diterima masyarakat luas sekarang ini adalah hubungan seks atau aktivitas seksual lainnya antara individu yang mempunyai hubungan dekat, yang perkawinan dilarang oleh hukum, agama maupun kultur.

Kartono (1989:225) menyebutkan bahwa incest banyak terjadi di kalangan rakyat dari tingkat kalangan sosial-ekonomi rendah. Jenis-jenis incest yang dilakukan ayah terhadap anak kandungnya biasanya akibat psikopatologi berat. Jenisini biasa terjadi antara ayah yang alkoholik atau psikopatik dengan anak perempuannya. Penyebabnya adalah kendornya kontrol diri akibat alkohol atau psikopati sang ayah; Incest akibat phedofilia, misalnyas eorang lelaki yang haus menggauli anak-anak perempuan di bawah umur, termasuk anak sendiri; Incest akibat patologi keluarga dan hubungan perkawinan yang tidak harmonis. Seorang suami-ayah yang tertekan akibat sikap memusuhi serba mendominasi dari istrinya bisa terpojok melakukan incest dengan anak perempuannya.

Faktor kondisi sosial yang sering memungkinkan pelanggaran incest adalah rumah yang sempit dengan penghuni yang berdesakan, alkoholisme, isolasi geografis, sehingga sulit mencari hubungan dengan anggota keluarga lain. Kartono (1989:225) menyebutkan bahwa penyebab incest adalah antara lain ruangan rumah yang tidak memungkinkan orang tua, anak, dan saudara pisah kamar. Sedangkan hubungan incest antara ayah dengan anak perempuannya dapat terjadi sehubungan dengan keberadaan penyakit mental yang serius pada pihak ayah.

Supratik (1995:101) mengatakan bahwa incest merupakan taraf koitus antara keluarga, misalnya antara kakak lelaki dengan adik perempuannya yang dimaksud adalah hubungan seksual. Atau antara ayah dengan anak perempuannya, yang dilarang oleh adat dan kebudayaan". Manik (2002:37) menyebutkan bahwa pengertian incest pada masa sekarang ini telah diperluas lagi meliputi peradaban pada genital, buah dada dan pantat, oral-genital dan hubungan seksual anak maupun vagina. Incest dapat terjadi suka sama suka yang kemudian bisa terjalin dalam perkawinan dan ada yang terjadi secara paksa yang lebih tepat disebut 
dengan perkosaan. Incest digambarkan sebagai kejadian relasi seksual, diantara individu yang berkaitan darah, akan tetapi istilah tersebut akhirnya dipergunakan secara lebih luas, yaitu untuk menerangkan hubungan seksual ayah dengan anak, antara saudara. Incest merupakan perbuatan terlarang bagi hampir setiap lingkungan budaya (Arsam, 2014:59).

Sadarjoen (2005:74) berkesimpulan bahwa dasar tabu incest adalah apabila incest dibenarkan maka akan terjadi persaingan, perebutan pasangan dalam lingkungan, antara ayahibu-saudara-saudara. Jelas bahwa persaingan atau perbuatan semacam itu akan membawa kehancuran keluarga dan suku bangsasen diri. Disposisi psikis yang dibawa sejak lahir akan tetap efektif apabila mendapat persaingan tertentu daripada proses percampuran darah antara individu yang tidak ada kaitan darahnya.

Fakta biologis juga memperkuat tabu incest karena kematian, retardasi mental dan kelalaian congenital sangat banyak terjadi sebagai akibat incest. Lustig (1966:39) menyatakan terdapat lima kondisi gangguan keluarga yang memungkinkan melakukan kejahatan incest, yaitu:

1) Keadaan terjepit, dimana anak perempuan menjadi figure perempuan utama yang mengurus keluarga dan rumah tangga sebagai pengganti ibu;

2) Kesulitan seksual pada orang tua, ayah tidak mampu mengatasi dorongan seksual;

3) Ketidakmampuan ayah untuk mencari pasangan seksual di luar rumah karena kebutuhan untuk mempertahankan facade kestabilan sifat patriarkhinya;

4) Ketakutan akan perpecahan keluarga yan gmemungkinkan beberapa anggota keluarga untuk lebih memilih desintegrasi struktur daripada pecah sama sekali;

5) Sanksi yang terselubung terhadap ibu yang tidak berpartisipasi dalam tuntutan peranan seksual sebagai istri.

Korban incest biasanya adalah anak-anak, karena biasanya perkosaan incest terjadi tanpa ada perlawanan yang berarti dan relatif menimbulkan trauma fisik, karena biasanya anak-anak cenderung menyerah tanpa melawan (karena tidak memahami apa yang terjadi pada dirinya). Sedangkan pelaku kekerasan, biasanya melakukan dengan menggunakan bujukan akan memberi imbalan tertentu, seperti jajanan, permen, atau uang sehingga anak 
merasa senang. Selainitu, faktor penyebab anak- anak ini menyerah begitu saja adalah orang yang mereka percaya atau mereka sayangi (telah mengenal mereka cukup dekat).

\section{Posisi Gender dalam Kejahatan Incest yang Dilakukan Ayah terhadap Anak Kandungnya}

Kejahatan incest bukan hanya terjadi karena ada niat pelaku tetapi juga karena adanya kesempatan. Posisi istri tersudutkan ketika terjadi incest yang dilakukan suaminya. Istri dianggap tidak dapat memuaskan keinginan suami, sehingga suami memerkosa anaknya sendiri. Hal ini dijadikan pelaku sebagai alasan dari tindakan yang dilakukan. Padahal kejahatan tersebut merupakan suatu penyakit atau kelainan seperti yang sudah disebutkan di atas. Pola hubungan suami istri dalam keluarga juga dapat mempengaruhi psikologi orangorang dalam keluarga tersebut.

Scanzoni (Via Lustig, 1966:35) mengungkapkan bahwa hubungan suami-istri dapat dibedakan menurut pola perkawinan yang ada. Mereka menyebut ada 4 macam pola perkawinan yaitu owner property, head complement, senior junior partner, dan equal partner.

a. Pada pola perkawinan owner property, istri adalah milik suami sama seperti uang dan barang berharga lainnya. Tugas suami adalah mencari nafkah dan tugas istri adalah menyediakan makanan untuk suami dan anak-anak dan menyelesaikan tugas-tugas rumah tangga yang lain karena suami telah bekerja untuk menghidupi dirinya dan anak-anaknya.

b. Pada pola perkawinan yang head-complement, istri dilihat sebagai pelengkap suami. Suami diharapkan untuk memenuhi kebutuhan istri akan cinta dan kasih sayang, kepuasan seksual, dukungan emosi, teman, pengertian dan komunikasi yang terbuka. Suami dan istri memutuskan untuk mengatur kehidupan bersamanya secara bersama-sama. Tugas suami masih tetap mencari nafkah untuk menghidupi keluarganya,dan tugas istri masih tetap mengatur rumah tangga dan mendidik anak-anak. Tetapi suami dan istri kini bisa merencanakan kegiatan bersama untuk mengisi waktu luang. 
c. Pada pola perkawinan senior-junior partner, posisi istri tidak lebih sebagai pelengkap suami, tetapi sudah menjadi teman. Perubahan ini terjadi karena istri juga memberikan sumbangan secara ekonomis meskipun pencari nafkah utama tetap suami. Dengan penghasilan yang didapat, istri tidak lagi sepenuhnya tergantung pada suami untuk hidup. Kini istri memiliki kekuasaan yang lebih besar dalam pengambilan keputusan. Tetapi suami masih memiliki kekuasaan yang lebih besar dari istri karena posisinya sebagai pencari nafkah utama. Ciri perkawinan seperti inilah yang banyak terdapat sekarang ini. Istri bisa melanjutkan sekolah asal sekolah atau karier suami didahulukan. Istri juga bisa merintis karirnya sendiri setelah karir suami sukses. Dalam pola perkawinan seperti ini istri harus mengorbankan kariernya demi karir suaminya. Tugas istri yang utama adalah mengatur rumah tangga dan memberikan dukungan pada suami sehingga suami bisa mencapai maju dalam pekerjaannya. Suami mempunyai seseorang yang melengkapi dirinya. Mereka juga diharapkan untuk bisa menikmati kehadiran pasangannya sebagai pribadi, menemukan kesenangan dari kehadiran itu, saling percaya, dan berbagai masalah, pergi dan melakukan kegiatan bersamasama.

d. Pada pola perkawinan equal partner, tidak ada posisi yang lebih tinggi atau rendah diantara suami-istri. Istri mendapat hak dan kewajibannya yang sama untuk mengembangkan diri sepenuhnya dan melakukan tugas-tugas rumah tangga. Pekerjaan suami sama pentingnya dengan pekerjaan istri. Dengan demikian istri bisa pencari nafkah utama, artinya penghasilan istri bisa lebih tinggi dari suaminya. Dalam hubungan ini, alasan bekerja bagi wanita berbeda dengan alasan yang dikemukakan dalam pola perkawinan sebelumnya. Alasan untuk bekerja biasanya menjadi "sekolah untuk kerja" atau“supaya mandiri secara penuh."

\section{Pemberitaan Perempuan di Media}

Peranan pers menjadi krusial ketika dihadapkan pada kenyataan- kenyataan bahwa sebenarnya merekalah yang mampu membentuk dan memobilisasi opini publik. Pers 
merupakan alat kepentingan yang paling efektif guna tujuan-tujuan tertentu yang bersifat masif. Media, kelompok-kelompok elit dan institusi-institusi kekuasaan mempunyai pengaruh yang cukup signifikan, langsung maupun tidak langsung dalam kehidupan masyarakat umum. Demikian juga pers mempunyai pengaruh yang besar terhadap masyarakat dalam berbagai ruang kehidupan yang berbeda.

Media sanggup memberikan berbagai macam hal baru bagi para penggunanya. Media pun dalam beberapa fenomena, juga dapat mengubah serta mengarahkan situasi sosial dari masyarakat penggunanya. McQuail (2004:41) menyebutkan media mampu menimbulkan adanya audiens atau konsumen dalam jumlah banyak, serta mampu menyamakan opini dan kepercayaan serta sikap dari penggunanya. Dalam hubungannya dengan kehidupan sosial manusia, pengaruh media massa juga terasa pada kehidupan sosial perempuan.

Stigma dan stereotip yang terbentuk di masyarakat mengenai perempuan sedikit banyak dipengaruhi oleh media. Media menyajikan citra perempuan secara arbitrer atau sewenang-wenang, seringkali tanpa memikirkan dampak yang bisa timbul dari citra yang dibangun tersebut. Citra perempuan yang dibangun dalam media disesuaikan dengan kebutuhan para pelaku bisnis dan industri yang berada di belakang layar. Seringkali perempuan dijadikan objek agar tujuan industri tercapai, misalnya rating yang tinggi. Perempuan dijadikan sebagai objek melalui cara yang bervariasi. Cara yang paling ampuh dan paling sering digunakan adalah dengan melakukan eksploitasi berlebihan terhadap tubuh perempuan. Sharma (2012:5) juga mengungkapkan bahwa, eksploitasi tubuh perempuan yang divisualisasikan dalam bentuk konten media seolah-olah menjadikan tubuh perempuan sebagai alat tukar dengan keuntungan pelaku industri. Tubuh perempuan yang diekspos oleh media menjadikan perempuan sebagai objek yang bisa diperjualbelikan, dengan timbal balik berupa rating, laba industri, peningkatan pengguna media massa dan seterusnya.

Media massa dipercaya mampu mempengaruhi masyarakat untuk menerima cara pandang baru atas suatu persoalan. Dalam memberitakan masalah kekerasan pada perempuan, setiap media memiliki wacana yang berbeda-beda dalam menanggapi suatu permasalahan. Ada media massa yang melihat peristiwa-peristiwa kekerasan pada perempuan sebagai bahan 
untuk komodifikasi semata, dimana aspek sensasi lebih banyak ditonjolkan dibandingkan dengan substansi kejadiannya.

Judul berita yang mengundang sensasional begitu marak dipakai oleh sejumlahmedia massa. Nampaknya, topik seksualitasdalam bingkai kekerasan (termasuk pemerkosaan) tidak saja menjadi primadona bagi kalangan masyarakat, namun juga bagi kalangan media. Kekerasan pada perempuan, misal pemerkosaan dalam kemasan jurnalistik seakan-akan tidak lagi dipandang sebagai kejahatan kemanusiaan yang sama sekali bertentangan dengannilainilaikemanusiaan.Justru tindakantersebutdimanfaatkansebagai strategi pasar. Ditambah lagi sajian jurnalistikitumendapat apresiasi publik yang cukup besar (Hartanto, 2009:56).

Membahas masalah berita tidaklah lengkap jika tidak membahas juga apa yang disebut berita sensasi. Berita sensasi ialah berita yang menekankan secara berlebihan'unsur manusia'dalam pemberitaan, yakni perasaan atau emosi. Perkataan sensasi yang berasal dari bahasa Inggris sensation, dari akar kata sense, sudah cukup menggambarkan apa yang disebut berita sensasi, yakni berita yang isinya, dan terutama cara mengemukakannya, terlalu didasarkan pada keinginan untuk menarik perhatian, membangkitkan perasaan atau emosi. Dengan demikian berita sensasi sedikit sekali didasarkan pada nalar atau sama sekali tidak didasarkan pada nalar yang sehat (Kusumaningrat dan Kusumaningrat, 2005:66-67).

Sudibyo (2001:7-10) mengungkapkan, penelitian dalam level produksi berita, seringkali dipusatkan pada proses penulisan berita. Berita merupakan produk media yang telah melewati proses yang kompleks dari sebuah organisasi media massa. Pembentukan berita dipandang bukanlah ruang yang hampa, netral, dan seakan-akan hanya menyalurkan informasi. Akan tetapi sebaliknya, proses tersebut rumit dan banyak faktor yang berpotensi untuk mempengaruhinya. Mulai dari faktor individual, seperti latar belakang profesional dari pengelola berita, serta faktor rutinitas media yang berhubungan dengan mekanisme dan proses penentuan berita. Selain itu juga organisasi yang membawahi individu-individu pengelola media. Faktor luar media juga turut mempengaruhi konstruksi berita.Terakhir ialah sumber berita, yaitu sumber berita yang tidaknetral dan memiliki tujuan tertentu. 
Fairclough dan Wodak (dalam Hartanto, 2009:23) menyatakan bahwa, wacana pemakaian berita dalam tuturan dan tulisan sebagai bentuk dari praktik sosial. Wacana memberi gambaran sebagai sebuah praktik sosial yang menyebabkan sebuah hubungan dialektis diantara peristiwa diskursif tertentu dengan situasi, institusi, dan struktur sosial yang membentuknya. Juga dapat menampilkan efek ideologi, ia dapat memproduksi dan mereproduksi hubungan kekuasaan yang tidak imbang antara kelas sosial, laki-laki dan wanita, kelompok mayoritas dan minoritas melalui mana perbedaan itu direpresentasikan dalam posisi ruang ditampilkan.

Posisi sebagai subjek dan objek dalam representasi ini mengandung muatan ideologis tertentu. Pertama, posisi ini menunjukkan dalam batas tertentu sudut pandang penceritaan. Artinya, seluruh peristiwa pemerkosaan ini (bukan hanya peristiwa tetapi juga gambaran aktor-aktornya). Kedua, sebagai subjek representasi, pihak laki-laki disini mempunyai otoritas penuh dalam mengabsahkan penyampaian peristiwa tersebut kepada pembaca. Karena posisinya sebagai subjek, ia bahkan bukan hanya mempunyai keleluasaan menceritakan peristiwa tetapi juga menafsirkan berbagai tindakan yang membangun peristiwa tersebut, dan kemudian hasilpenafsirannya mengenai peristiwa itu digunakan untuk membangun pemaknaan dia yang disampaikan kepada khalayak. Ketiga, karena proses pendefinisian ini bersifat subjektif, tentu saja sukar dihindari kemungkinan pendefinisian secara sepihak peristiwa atau kelompok lain. Ia bukan hanya mendefinisikan dirinya sendiri tetapi juga mendefinisikan pihak lain dalam persepktif atau sudut pandangnya sendiri.

\section{Model Analisis Wacana Kritis Van Dijk}

Suatu teks terdiri atas beberapa struktur yang masing-masing bagian saling mendukung. Van Dijk (1997) mengungkapkan bahwa strukur wacana adalah yang efektif untuk melihat proses retorika dan persuasi yang dijalankan ketika seseorang menyampaikan pesan. Struktur wacana terbagi dalam tiga tingkatan yaitu struktur makro, superstruktur, dan struktur mikro. Hal tersebut dijabarkan sebagai berikut.

\section{Mikrostruktur}

Struktur mikro merupakan analisis sebuah teks berdasarkan unsur-unsur intrinsiknya. Makna wacana dalam struktur mikro dapat diamati dari bagian kecil dari suatu teks yakni kata, 
kalimat, proposisi, anak kalimat, parafrase, dan gambar. Unsur-unsur intrinsik tersebut meliputi.

a. Unsur semantik yang dalam hal ini dikategorikan sebagai makna lokal (local meaning), yakni makna yang muncul dari kata, klausa, kalimat, dan paragraf, serta hubungan di antara mereka, seperti hubungan antarkata, hubungan antarklausa, antarkalimat, dan antarparagraf, yang membangun suatu kesatuan makna dalam satu kesatuan teks.

Van Dijk(1997:9) menyatakan pada tingkat mikro, yang berarti hubungan antara proposisi dari wacana mematuhi sejumlah kondisi secara koheren. Misalnya satu proposisi dapat berfungsi sebagai spesifikasi, generalisasi, ilustrasi atau kontras sehubungan dengan sebelumnya. Kalimat kedua tersebut mengekspresikan proposisi yang merupakan generalisasi dari proposisi diungkapkan dalam kalimat pertama.

Struktur pembangun wacana (tertulis) kalimat atau ucapan dalam unit terkecil dari wacana adalah untuk menyampaikan tentang konten yang sama dalam sebuah cara yang berbeda. Seperti dalam (Renkema, 2004:87) "the building blocks for discourse are(written) sentences or (spoken) utterances. Within these smallest units of discourse it is possible to convey about the same content in a number of different ways."

b. Semantik wacana tidak terbatas pada hubungan makna fungsional atau makna lain yang berhubungan dengan proposisi. Semantic wacana juga memerlukan gagasan lain yaitu referens. Referen merupakan cara dan makna berhubungan dengan peristiwa nyata atau imajinasi yang dibicarakan.

c. Unsur sintaksis merupakan salah satu elemen yang membantu pembuat teks untuk memanipulasi keadaan dengan jalan penekanan secara tematik pada tatanan kalimat. Manipulasi tersebut dapat berupa pemilihan penggunaan kata, kata ganti, preposisi, dan konjungsi, serta pemilihan bentuk-bentuk kalimat seperti kalimat aktif dan pasif.

d. Unsur stilistik merupakan unsur style atau ragam tampilan sebuah teks dengan menggunakan bahasa sebagai sarananya. Sebuah teks bisa memilih berbagai ragam tampilan seperti puisi, drama, atau narasi. Terkait dengan gaya bahasanya, sebuah teks bisa menampilkan style melalui diksi atau pilihan kata, pilihan kalimat, majas, matra, atau ciri kebahasaan yang lainnya. 
e. Unsur retoris merupakan unsur yang berhubungan erat dengan bagaimana dan dengan cara penekanan dilakukan. Hal tersebut meliputi grafis, metapora, dan ekspresi.

2. Makrostruktur

Struktur makro merupakan makna global dari sebuah teks yang dapat dipahami dengan melihat topik dari sebuah teks. Dengan kata lain, analisis struktur makro merupakan analisis sebuah teks yang dipadukan dengan kondisi sosial di sekitarnya untuk memperoleh satu tema sentral. Tema sebuah teks tidaklah terlihat secara eksplisit di dalam teks, melainkan tercakup di dalam keseluruhan teks secara satu kesatuan bentuk yang koheren. Jadi, tema sebuah teks dapat ditemukan dengan cara membaca teks tersebut secara keseluruhan sebagai sebuah wacana sosial sehingga dapat ditarik satu ide pokok atau topik atau gagasan yang dikembangkan dalam teks tersebut.

Struktur makna disebut makrostruktur dalam wacana. Van Dijk menggunakan istilah makrostruktur untuk menyatakan struktur makna. Istilah ini merupakan kebalikan dari istilah mikrostruktur yang digunakan untuk menyatakan hubungan antara kalimat dan unsur kalimat dalam proposisi.

3. Superstruktur

Superstruktur merupakan kerangka dasar sebuah teks yang meliputi susunan atau rangkaian struktur atau elemen sebuah teks dalam membentuk satu kesatuan bentuk yang koheren. Dengan kata lain, analisis superstruktur merupakan analisis skema atau alur sebuah teks. Seperti halnya sebuah bangunan, sebuah teks juga tersusun atas berbagai elemen, seperti pendahuluan, isi, dan penutup yang harus dirangkai sedemikian rupa, guna membentuk sebuah teks yang utuh dan menarik.

Superstruktur merupakan struktur formal dalam wacana. Jika struktur makro berkaitan dengan struktur isi, maka superstruktur berkaitan adengan bentuk wacana atau skema yang digunakan dalam wacana. Hal itu dijelaskan oleh Renkema (2004:97) "Superstructures are conventionalized schemas that provide the global form from the macrostructural content of discourse. In other words, macrostructures deal with the content and superstructures with the form. 
Topik dalam penelitian sering dianggap sebagai superstruktur. Artikel surat kabar sering memiliki struktur yang merepresentasikan headline, lead, dan flat tex. Headline dalam artikel surat kabar terdapat dalam subjudul yang memuat ringkasan atau gambaran singkat mengenai isi berita. Lead mengandung intisari dari berita. Sementara flat text menjelaskan detail berita. Namun, Renkema berpendapat bahwa ketiga bagian dari skema ini belum mampu menjelaskan isi berita secara lengkap (2004:98).

Sebuah teori dalam berita dapat mengasumsikan bahwa pembaca akan memperoleh lebih banyak informasi mengenai sebuah berita sebelum mengetahui isi berita. Berdasarkan teori tersebut kemudian diperoleh hipotesis. Hipotesis berisi simpulan berita. Hipotesis ini kemudian dapat dites dan diujicobakan. Desain eksperimen akan memberikan informasi kepada pembaca mengenai subjek serta kondisi yang keduanya dijelaskan dalam laporan. Desain tersebut juga harus mampu menjelaskan bagaimana eksperimen berlangsung. Pada akhirnya, pembaca dapat menemukan pertanyaan dan jawaban yang menjadi permasalahan dalam hipotesis untuk dijadikan sebuah kesimpulan.

\section{METODE PENELITIAN}

Penelitian ini menggunakan metode kualitatif dengan menggunakan pendekatan analisis wacana kritis van Dijk. Pendekatan analisis diskursus berbeda dengan pendekatan fenomenologi yang percaya terhadap otonomi subjek. Analisis wacana memiliki kajian yang berbeda, yakni unit bahasa. Bahasa memiliki keterkaitan antarateks (pernyataan) dankonteks(praktik)(Mills, 2007:9). Analisis wacana percaya bahwa bahasa bukan medium berekspresi. Namun, bahasa sebagai medium dominasi dan penyebaran kekuasaan. Teknik pengumpulan data dilakukan dengan cara mengumpulkan berita. Berita yang dikumpulkan dari satu media yaitu Merdeka.com. 5 teks telah dipilih, yakni Alasan Konyol Orang Tua Tega Memerkosa Anak Kandung (teks 1), Kesal Karena Anak Tak Perawan Lagi (teks 2), Jarang Dilayani Istri (teks 3), Kalut Istri Tak Kunjung Pulang Jadi TKW (teks 4), Ditolak Berhubungan Badan Sama Istri (teks 5). Teks-teks tersebut diolahdan dianalisisberdasarkan perspektifteoritis yangdigunakan.

\section{HASIL DAN PEMBAHASAN}

\section{Analisis Teks}


Renkema (2004: 34-37) mengatakan bahwa untuk mempertimbangkan apakah satuan lingual itu dapat dikatakan sebagai wacana atau bukan dibutuhkan tujuh kriteria. Ketujuh kriteria itu ialah:

1. Kekohesian, yaitu hubungan yang dihasilkan pada saat interpretasi suatu unsur bergantung pada unsur lain di dalam teks.Ini berarti kekohesian menyangkut hubungan semantis antar unsur di dalam teks. Ditemukan unsur kohesi yakni referensi, konjungsi, dan repetisi dalam teks Intro.

a. Referensi

Teks (1) tidak ditemukan kataforis. Anaforis yang merupakan pencarian tafsiran ke belakang di dalam teks, ditemukan dalam teks (1) yang merupakan Intro berita.

(1.1) Ayah memerkosa anak kandung bukan lagi peristiwa yang mengejutkan. Sebab, dari hari ke hari peristiwa keji tersebut makin marak terjadi.

(1.2) Ayah memerkosa anak kandung bukan lagi peristiwa yang mengejutkan. Parahnya, akibat perbuatan kotor itu ada korban yang sampai melahirkan.

(1.3) Parahnya, akibat perbuatan kotor itu ada korban yang sampai melahirkan. Ini pun menjadi kenyataan pahit yang dua kali diterima keluarga korban.

(1.4) Akan tetapi, di balik itu terdapat alasan konyol yang menyebabkan sang ayah tega merenggut kehormatan putri kandungnya tersebut.

Teks (2) tidak ditemukan kataforis. Anaforis yang merupakan pencarian tafsiran ke belakang di dalam teks, ditemukan dalam teks (2), yakni sebagai berikut:

(2.1) Husein Jaelani (43), warga Desa Pasanggrahan, Kecamatan Kasomalang, Kabupaten Subang, Jawa Barat, tega mencabuli anak kandungnya sendiri berinisial C (14).

(2.2) Husein Jaelani (43), warga Desa Pasanggrahan, Kecamatan Kasomalang, Kabupaten Subang, Jawa Barat, tega mencabuli anak kandungnya sendiri berinisial C (14). Husein melakukan perbuatan kotor itu lantaran tergoda kemolekan tubuh anaknya.

(2.3) Husein Jaelani (43), warga Desa Pasanggrahan, Kecamatan Kasomalang, Kabupaten Subang, Jawa Barat, tega mencabuli anak kandungnya sendiri 
DIMENSI, VOL. 8, NO. 1 : 142-166

MARET 2019

ISSN: 2085-9996

berinisial $C$ (14). Husein melakukan perbuatan kotor itu lantaran tergoda kemolekan tubuh anaknya.

(2.4) Husein Jaelani (43), warga Desa Pasanggrahan, Kecamatan Kasomalang, Kabupaten Subang, Jawa Barat, tega mencabuli anak kandungnya sendiri berinisial C (14). Pria yang bekerja sebagai buruh serabutan ini sudah mencabuli C selama empat tahun.

(2.5) Akan tetapi, korban akhirnya memberanikan diri menceritakan kejadian yang dialaminya kepada pamannya.

(2.6) Kapolsek Jalan Cagak, Kompol Yanto mengatakan, pihaknya langsung memanggil orang tua korban setelah menerima laporan peristiwa pencabulan itu.

Teks (3) tidak ditemukan kataforis. Anaforis yang merupakan pencarian tafsiran ke belakang di dalam teks, ditemukan dalam teks (3), yakni sebagai berikut:

(3.1) Polisi terus melakukan pemeriksaan terhadap Deden Priyatna (43), ayah yang tega memperkosa anak perempuannya sebanyak 60 kali sejak 2008 silam.

(3.2) "Iya, ada permasalahan dengan keluarga ketika ada konflik dengan istri. Kejadian sudah lama waktu itu ketika kembali dari Kalimantan, istri sudah tidak sering ngasih jatah," ujar Deden, Selasa (19/2).

(3.3) Iya, ada permasalahan dengan keluarga ketika ada konflik dengan istri. Deden menuturkan sejak permasalahan itu dirinya dan istri jadi jarang melakukan hubungan suami istri.

(3.4) Sementara itu dikatakan pria yang berprofesi sebagai makelar penjualan mobil ini, selain menyetubuhi istrinya ia juga masih tetap meniduri anaknya jika malam hari.

(3.5) "Sama istri masih, sebulan sekali, lebih sering sama anak," katanya.

(3.6) Lebih lanjut Deden mengatakan, saat memaksa sang anak berhubungan intim, dirinya kerap kali mengancam akan merusak keluarganya jika perbuatan tersebut dilaporkan kepada sang ibu atau keluarga lainnya. 
(3.7) Lebih lanjut Deden mengatakan, saat memaksa sang anak berhubungan intim, dirinya kerap kali mengancam akan merusak keluarganya jika perbuatan tersebut dilaporkan kepada sang ibu atau keluarga lainnya.

(3.8) Kanit PPP AKP Endang ... "Tidak ada kelainan, kalau dilihat pelaku ini memanfaatkan celah lengah ketika malam hari," katanya.

Teks (4) tidak ditemukan kataforis. Anaforis yang merupakan pencarian tafsiran ke belakang di dalam teks, ditemukan dalam teks (4), yakni sebagai berikut:

(4.1) Agus Hadi Pranoto (53) contoh seorang bapak tidak bertanggung jawab, dengan perilakunya yang bejat. Betapa tidak, karena alasan kebutuhan biologis, anak sendiri ditiduri hingga hamil dan melahirkan.

(4.2) Agus Hadi Pranoto (53) ... Tersangka berdalih, istrinya menjadi Tenaga Kerja Wanita (TKW) di Hong Kong.

(4.3) Betapa tidak, karena alasan kebutuhan biologis, anak sendiri ditiduri hingga hamil dan melahirkan. Perbuatan bejat itu diakui tersangka telah dilakukan sebanyak tiga kali pada pertengahan 2015.

(4.4) karena alasan kebutuhan biologis, anak sendiri ditiduri hingga hamil dan melahirkan. Pelaku harus mempertanggungjawabkan atas perbuatannya.

(4.5) karena alasan kebutuhan biologis, anak sendiri ditiduri hingga hamil dan melahirkan. Perbuatan tersangka diancam Pasal 81-82 Junto Pasal 76D-76E Undang-undang nomor 35 Tahun 2014 tentang Perlindungan Anak.

(4.6) Agus Hadi Pranoto (53) contoh seorang bapak tidak bertanggung jawab, dengan perilakunya yang bejat. Pelaku tercatat sebagai warga Desa Ngebruk, Kecamatan Sumberpucung, Kabupaten Malang.

(4.7) Pelaku tercatat ... Ia berdalih kalut ...

Teks (5) tidak ditemukan kataforis. Anaforis yang merupakan pencarian tafsiran ke belakang di dalam teks, ditemukan dalam teks (5), yakni sebagai berikut:

(5.1) Ahmad Yani (50) tega memperkosa anak kandungnya, Bunga (nama samaran, 13 tahun) belasan kali hingga hamil tiga bulan. 
(5.2) Ahmad Yani (50) tega memperkosa anak kandungnya, Bunga (nama samaran, 13 tahun) belasan kali hingga hamil tiga bulan. Perbuatan itu dilakukannya saat tidur seranjang bersama sang istri.

(5.3) Ahmad Yani (50) tega memperkosa anak kandungnya, Bunga (nama samaran, 13 tahun) belasan kali hingga hamil tiga bulan. ... dari pengakuan tersangka, perkosaan dilakukan di kamar rumahnya saat malam hari secara diam-diam, sehingga tidak membangunkan istrinya yang sedang tidur.

(5.4) Ahmad Yani (50) tega memperkosa anak kandungnya, ... Meski belasan kali melakukan perbuatan itu, istri Yani tak pernah mengetahuinya.

(5.5) Ahmad Yani (50) tega memperkosa anak kandungnya, Bunga (nama samaran, 13 tahun) belasan kali hingga hamil tiga bulan. Korban juga diminta tidak mengadu ke ibunya.

(5.4) Berdasarkan keterangan Yani,dia nekat memperkosa anak kandungnya karena selalu ditolak istrinya berhubungan badan.

(5.5) Penolakan istri tersangka lantaran dia kelelahan karena bekerja seharian sebagai buruh perkebunan sawit.

b. Konjungsi

Ditemukan konjungsi dalam teks (1) yaitu, bukan lagi, sebab, ini pun, dan akan tetapi. Konjungsi pada teks (2) yaitu, selain itu, karena, akan tetapi, dan kemudian. Konjungsi teks (3) yaitu, bahwa, karena, dan, sementara itu, selain, juga, jika, lebih lanjut, jika, atau, dan ketika. Konjungsi teks (4) yaitu, betapa tidak, karena, hingga, dan, sedangkan, sehingga, oleh, atas, bahkan. Konjungsi teks (5) yaitu, hingga, sehingga, juga, saat itulah, meski, kemudian, dengan, juga, bahkan, selama ini, berdasarkan, karena, alhasil, namun, dan dengan.

c. Repetisi

Ditemukan repetisi dalam teks (1) yaitu, memerkosa, konyol dan anak kandung. Repetisi pada teks (2) yaitu, mencabuli, anak kandung, dan tidak perawan. Repetisi pada teks (3) yaitu, memperkosa, anak perempuan, sang istri, dan ibu. Repetisi pada teks (4) 
yaitu, anak sendiri dan istri. Repetisi pada teks (5) yaitu, memperkosa, anak kandung, sang istri, ibu, dan tersangka.

2. Kekoherensian,yaituhubungan yang didasari oleh sesuatu yang datangnya dari luar teks. Sesuatu tersebut mengacu pada pengetahuan dan pengalaman yang dimiliki oleh penuturatau petutur. Pengetahuan dan pengalaman tentang pemerkosaan ataupun pencabulan membuat jurnalis dan pembaca memiliki sesuatu yang sudah diketahui sebelumnya. Hal ini mempengaruhi jurnalis dalam membuat berita pemerkosaan ataupun pencabulan, juga mempengaruhi interpretasi pembaca ketika membaca berita terkait pencabulan maupun pemerkosaan.

3. Keintensionalan, menyangkut tujuan dan fungsi bahasa yang dimiliki partisipan dalam berkomunikasi. Sikap pengujar (penghasil teks) mengenai serangkaian peristiwa pengujarannya. Dalam sikap tersebut, peristiwa-peristiwa ujarannya dibuat sedemikian rupa sehingga memenuhi persyaratan keinstrumenan teks yang terpadu dan berpadu untuk memenuhi maksudnya. Jurnalis dalam membuat berita pemerkosaan, menggunakan kata atau diksi yang khusus dalam bidang kriminal. Pemilihan diksi tersebut disesuaikan dengan pasar medianya. Untuk kalangan menengah ke atas ataupun menengah ke bawah, agar pemahaman konsep dapat cenderung sama dan benar. Penggunaan diksi oleh jurnalis (media) sangat mampu mempengaruhi dan menggiring pemikiran pembaca sesuai dengan keinginan jurnalis (media). Judul dari 4 teks terkait pemberitaan ayah perkosa anak kandung di Merdeka.com 3 diantaranya menyudutkan posisi istri dalam kasus tersebut. Alasan-alasan suami memerkosa anak kandung diberitakan Merdeka.com yang memyudutkan istri, seperti pada teks (2) dengan judul “Jarang Dilayani Istri”, teks (3) dengan judul "Kalut Istri Tak Kunjung Pulang Jadi TKW”, dan teks (4) dengan judul "Ditolak Berhubungan Badan Sama Istri”.

4. Keberterimaan, mengacu pada rangkaian kalimat yang berterima dan dapat dipahami oleh petutur atau pembaca agar dapat dikualifikasikan sebagai teks. Keberterimaan terkait sikap penerima teks mengenai serangkaian peristiwa pengujaran, yang di dalamnya dipersyaratkan bahwa serangkaian persitiwa ujaran tersebut harus merupakan teks yang kohesif dan koheren sehingga berguna atau relevan bagi penerima teks tersebut. 
Pembaca yang membaca pemberitaan Merdeka.com dalam kasus ayah perkosa anak kandung ini memahami alasan-alasan yang dihimpun oleh jurnalis. Dari 4 teks yang dihimpun, 3 diantaranya memberikan alasan bahwa kesalahan atas pemerkosaan yang dilakukan ayah terhadap anak kandung itu dikarenakan oleh kesalahan istri.

5. Keinformatifan,berartibahwasuatu teks harus memuat informasi-informasi baru dan harus dapatdipahami oleh interlokutor. Teks-teks yang dibuat oleh Merdeka.com ini mengandung informasi terkait alasan apa saja yang menyebabkan ayah tega memerkosa anaknya sendiri. Akan tetapi, tahap solusi belum terlihat dalam teks-teks yang disajikan.

6. Kesituasionalan, menyangkut situasi tempat danwaktu teks tersebutdihasilkan. 4 teks pemberitaan terkait perkosaan yang dilakukan ayah terhadap anak kandungnya, sudah sesuai situasi dihimpun dalam judul "Alasan Konyol Orang Tua Tega Memerkosa Anak Kandung". Kasus perkosaan yang dilakukan ayah terhadap anak kandungnya semakin banyak terjadi, sehingga langkah Merdeka.com untuk mengumpulkan semua kasus yang sama ini dapat membantu khalayak dalam mengantisipasi dan melindungi diri sendiri.

7. Keintertekstualan, mengacu pada keterhubungan suatu wacana dengan wacana lain yang telah diketahui. Kasus yang dihimpun jurnalis Merdeka.com terkait alasan pemerkosaan yang dilakukan ayah terhadap kandung ini memberikan keadaan yang bertalian dengan faktor-faktor yang menyebabkan ketergantungan pemanfaatan suatu teks pemerkosaan terhadap pengetahuan mengenai satu teks pemerkosaan yang dijumpai terdahulu atau lebih.

\section{Analisis Wacana Kritis Model Van Dijk dalam Teks Pemberitaan Ayah Perkosa Anak} Kandung pada Media Online, Merdeka.com.

\section{Struktur Makro}

Teks (1) berperan sebagai intro yang mengantarkan pembaca untuk mengetahui alasanalasan yang dianggap konyol para orangtua yang tega memerkosa anak kandungnya. Belum ditemui sub-subtopik dalam teks (1) dikarenakan teks ini masih bersifat pengantar. Gagasan van Dijk yang memandang suatu peristiwa didasarkan pada mental atau pikiran tertentu. Topik 
atau tema dipahami sebagai mental atau kognisi jurnalis, sehingga semua elemen dalam berita mengacu dan mendukung topik dalam berita.

Topik dalam teks (2) adalah alasan ayah mencabuli anak kandungnya karena anak tidak perawan. Subtopik dalam teks (2) ialah tersangka tergoda dengan kemolekan tubuh anaknya.

Topik dalam teks (3) adalah alasan ayah perkosa anak kandungnya karena jarang dilayani istri. Kesalahan dari istri yang tidak mau melayani suaminya dijadikan angle oleh jurnalis dari pemberitaan di teks (3). Subtopik dalam teks (3) ialah konflik dengan istri menyebabkan pemerkosaan terhadap anaknya; jarang melakukan hubungan suami-istri; selain meniduri istri juga meniduri anak; mengancam anak agar tidak melapor pada orang lain; tidak ada kelainan yang dialami tersangka; tersangka memanfaatkan celah lengah pada malam hari.

Topik dalam teks (4) adalah alasan ayah perkosa anak kandungnya karena istri tidak pulang-pulang. Topik yang diangkat jurnalis dalam teks (4) kembali mengambil angle kesalahan istri yang tidak pulang dari berkerja sebagai TKW di Hongkong. Subtopik dalam teks (4) ialah anak ditiduri hingga hamil dan melahirkan; anak kedua menjadi pelampiasan hasrat seksual; terancam hukuman 5 hingga 15 tahun penjara; istri menggugat cerai.

Topik dalam teks (5) adalah alasan ayah perkosa anak kandungnya karena istri menolak berhubungan badan. Topik yang diangkat jurnalis dalam teks (5) lagi-lagi mengambil angle kesalahan istri yang menyebabkan pemerkosaan. Subtopik dalam teks (5) pemerkosaan dilakukan saat tidur seranjang bersama sang istri; tersangka belasan kali memerkosa anaknya; mengancam tidak memberikan uang jajan; tetangga melaporkan kejadian perkosaan ke kantor polisi; penolakan istri untuk berhubungan badan karena lelah bekerja; tersangka terancam 15 tahun penjara.

\section{Superstruktur}

Kerangka teks (1), yakni bagian pendahuluan, isi, dan penutup sudah terlihat dan jelas. Bagian dan urutan tersebut sudah diskemakan dalam teks. Penutup pada teks (1) sengaja dibuat menggantung karena berisikan pengantar informasi untuk menuju teks-teks selanjutnya. Lead pada teks (1) menunjukkan tema yang ingin disampaikan oleh jurnalis dalam 
pemberitaan. Tahap summary (lead dan judul) dan story (isi berita) sudah utuh dan padu dari suatu teks.

Kerangka teks (2), yakni bagian pendahuluan, isi, dan penutup sudah terlihat dan jelas. Bagian dan urutan tersebut sudah diskemakan dalam teks. Judul pada teks (2) merupakan salah satu jawaban yang ingin disampaikan jurnalis dalam teks (1). Lead kurang sesuai dengan judul, karena alasan utama tersangka melakukan pencabulan disebabkan oleh kemolekan tubuh anaknya. Jurnalis memilih judul "kesal karena anak tak perawan lagi" yang mengubah persepsi pembaca untuk melihat kesalahan dari sisi anak yang sudah tidak bisa menjaga keperawanan. Judul pada teks (2) pro terhadap tersangka, karena perihal anak yang tidak perawan diekspose, sedangkan kesalahan ayah yang tidak bisa menahan nafsu akan kemolekan tubuh anaknya tidak dijadikan judul. Lead pada teks (2) menunjukkan tema yang ingin disampaikan oleh jurnalis dalam pemberitaan, dengan menyampingkan persoalan tergodanya ayah akan kemolekan tubuh anaknya. Kalimat akhir pada lead kembali menegaskan judul yang dibuat oleh jurnalis.

Kerangka teks (3), yakni bagian pendahuluan, isi, dan penutup sudah terlihat dan jelas. Bagian dan urutan tersebut sudah diskemakan dalam teks. Penutup di teks (3) berupa pernyataan yang sekaligus memberikan informasi kapan waktu yang rentan terjadinya pemerkosaan tersebut. Judul dan Lead sudah sesuai. Proses jalannya peristiwa dalam teks (3) juga sudah ditampilkan dengan baik. Jurnalis, dalam teks langsung memilih judul atau angle yang merugikan posisi istri. Komentar yang ditampilkan dalam teks belum lengkap, karena pihak istri tidak ada komentar apapun dalam teks.

Kerangka teks (4), yakni bagian pendahuluan, isi, dan penutup sudah terlihat dan jelas. Bagian dan urutan tersebut sudah diskemakan dalam teks. Lead dan judul tidak sesuai. Lead dibuat seharusnya mencerminkan judul yang ada, akan tetapi pada teks (3) jurnalis tidak menyingkronkan antara judul dan lead.Jurnalis membuat judul yang kembali menyudutkan posisi istri dengan mengambil angle istri yang tak pulang-pulang dari bekerja menjadi TKW, namun lead menceritakan tersangka yang ingin memenuhi kebutuhan biologis dengan meniduri anak hingga hamil. Di bagian penutup, jurnalis juga memilih kutipan tersangka yang 
berusaha menegaskan bahwa pemerkosaan terjadi karena kesalahan istri yang tak kunjung pulang dari bekerja.

Kerangka teks (5), yakni bagian pendahuluan, isi, dan penutup sudah terlihat dan jelas. Bagian dan urutan tersebut sudah diskemakan dalam teks. Lead dan judul kembali tidak sesuai. Lead dibuat seharusnya mencerminkan judul yang ada, akan tetapi pada teks (5) jurnalis tidak menyingkronkan antara judul dan lead.Jurnalis membuat judul yang kembali menyudutkan posisi istri. Judul yang dibuat jurnalis menyebutkan alasan pemerkosaan terjadi karena istri tidak ingin berhubungan badan, sedangkan lead tidak menyinggung alasan tersebut. Lead teks (5) menjelaskan pemerkosaan pada anak tersangka terjadi ketika tidur seranjang bersama istri. Isi cerita juga lebih banyak mengungkap kejadian pemerkosaan yang dilakukan tersangka berulang kali namun istri tak juga mengetahui. Terdapat kejanggalan dalam kasus ini. Sehingga di bagian penutup, jurnalis menuliskan pernyataan pihak kepolisian yang akan meminta keterangan istri tersangka.

\section{Struktur Mikro}

Jurnalis dalam menulis teks (1) mengemukakan latar belakang atas terungkapnya peristiwa pemerkosaan anak oleh ayah kandung yang terjadi belakangan ini. Judul dan lead yang dituliskan oleh jurnalis mulai memengaruhi pembaca. Jurnalis ingin menunjukkan bahwa pemerkosaan terhadap anak kandung yang dilakukan oleh ayahnya sendiri merupakan peritiwa yang tidak mengagetkan lagi karena intensitas kejadian tersebut sudah sering terjadi. Penggunaan kata "konyol" oleh jurnalis dalam teks (1) memberikan efek yang tidak menyudutkan tersangka.

Jurnalis dalam menulis teks (2) menggunakan kata mencabuli sehingga dalam kejadian ini kemungkinan tersangka sudah tidak terikat pernikahan. Tidak dijelaskan pula dalam teks posisi istri. Alasan konyol pertama dalam kasus ini ialah karena anak sudah tidak perawan lagi. Keperawanan menjadi masalah serius, hingga menyebabkan seorang anak harus dicabuli ayahnya hanya karena tidak perawan. Tidak dijelaskan atau diketahui dalam teks bagaimana ayah mengetahui anaknya tidak perawan lagi, akan tetapi jurnalis menulis alasan pertama yang menjadi penyebab adalah kemolekan tubuh anak, diikuti alasan karena mengetahui anaknya tak perawan lagi. Penggunaan kata "lagi" dalam kalimat tersebut mengindikasikan bahwa anak 
tersangka yang lain juga tidak perawan. Judul yang ditulis oleh wartawan membuat pembaca berfikir bahwa keperawanan menjadi penting dalam kasus ini. Anak juga disudutkan dalam kasus ini karena tidak memandang dari sudut pandang korban.

Jurnalis Merdeka.com dalam menulis judul pada teks (3) ini, kembali mengambil sudut pandang tersangka. Istri menjadi pihak yang disudutkan dalam pemberitaan. Tersangka tega memerkosa korban karena sudah jarang melakukan hubungan intim dengan istri. Istri juga kembali disebut dalam lead berita pada teks (3). Kata "istri" kembali ditulis dengan mengulang pernyataan bahwa tersangka tega memerkosa anak karena sempat memiliki masalah dengan istri. Hal tersebut kembali diulang dalam pernyataan langsung tersangka.

Jurnalis Merdeka.com dalam menulis teks (4) lagi-lagi menjadikan istri sebagai alasan dalam kasus ayah yang memerkosaan anak kandung. Angle yang dipilih jurnalis kembali menyudutkan istri dan mengambil sudut pandang dari tersangka. Istri yang bekerja menjadi TKW menjadi penyebab suami memuaskan kebutuhan biologis kepada anak kandungnya.

Jurnalis Merdeka.com dalam menulis teks (5), posisi istri kembali mengalami ketimpangan dalam pemberitaan. Istri yang lelah bekerja sehingga menolak melayani suami dijadikan alasan tersangka untuk beralasan pemerkosaan terhadap anaknya. Jurnalis Merdeka.com kembali mengambil angle yang merugikan posisi istri dalam keluarga melalui pemberitaan.

\section{Kognisi Sosial Jurnalis Merdeka.com dalam Memberitakan Kasus Ayah Perkosa Anak Kandung}

Jurnalis hidup dalam pandangan dan keyakinan masyarakat yang dapat memengaruhi pandangan jurnalis. Hal tersebut bergantung pada pengalaman, memori, dan interpretasi jurnalis. Teks-teks yang diambil adalah teks yang diproduksi oleh beberapa jurnalis Merdeka.com. Teks-teks para jurnalis tersebut kembali dihimpun oleh seorang jurnalis Merdeka.com yakni Desi Aditia Ningrum, untuk ditelusuri penyebab-penyebab ayah memerkosa anak kandungnya dengan mengubah judul dan memppertahankan isi yang sudah ada.

Dari judul yang dibuat oleh jurnalis perempuan ini, ke 4 teks yang ada dan 1 teks intro, 3 di antaranya menyudutkan posisi istri. Ketimpangan pemberitaan yang dilakukan 
dikarenakan pemilihan judul berita yang mengambil sudut pandang tersangka. Pemerkosaan terhadap anak kandung pun dianggap suatu tindakan yang konyol oleh jurnalis ini. Penggunaan kata "konyol" memberikan efek yang tidak parah, karena hanya memiliki makna sebatas "agak gila" dan terkesan permainan.

Jurnalis juga terkesan memaksakan judul yang diberitakan, karena 4 teks berita 3 diantaranya tak sesuai dengan judul. Teks berita yang ada tak diubah dari penulis aslinya (pertama) kemudian jurnalis selanjutnya (kedua) mengubah judul sesuai dengan proyeksi yang ingin disampaikan jurnalis atau media (Merdeka.com). Dalam pemberitaan ini, posisi istri sangat dirugikan. Citra seorang istri diberitakan berulang-ulang dengan image yang buruk sebagai penyebab ayah memerkosa anak kandungnya tanpa adanya check dan cross check sebagai syarat pemberitaan yang baik. Hal tersebut terbukti dari tidak ada satu pun pemberitaan yang mengklarifikasikan ke pihak istri, namun judul secara gamblang menyudutkan posisi istri.

\section{Konteks}

Kecenderungan anak perempuan dekat dengan ayahnya untuk melengkapi kekurangannya yang cenderung bisa disempurnakan dengan kelebihan ayahnya. Anak perempuandengan ayahnya akan lebih akrab daripada anak laki-laki. Sudah seharusnya ayah menyadari pentingnya mengapa ayah lebih memperhatikan anak perempuan.

Anak yang memiliki ikatan emosional positif dengan ayahnya sejak usia dini, akan tumbuh lebih bahagia dan memiliki emosi yang lebih tenang saat mereka dewasa. Demikian hasil penelitian terbaru yang dipimpin oleh seorang peneliti asal India. Anak-anak, khususnya mendapatkan keuntungan dari pengaruh ayah yang kuat saat mereka berusia tiga bulan. Ramchandani menemukan, bahwa masalah perilaku pada anak usia dini sering menyebabkan masalah kesehatan dan psikologis di masa dewasa yang bisa sulit untuk diatasi (www.Tempo.com)

Anak-anak cenderung memiliki masalah perilaku lebih besar ketika ayah mereka lebih jauh dan sibuk dengan urusannya sendiri, atau ketika ayah mereka jarang berinteraksi dengan anak-anaknya. Asosiasi ini cenderung lebih kuat untuk anak laki-laki daripada anak 
perempuan, menunjukkan bahwa mungkin anak laki-laki lebih rentan terhadap pengaruh ayah mereka sejak usia dini (www.Tempo.com).

\section{SIMPULAN}

Ketimpangan posisi istri pada kasus ayah perkosa anak kandung (Incest) dalam pemberitaan Merdeka.com ditemukan dalam teks-teks yang dihimpun jurnalis Desi Aditia Ningrum. 3 dari 4 teks yang dihimpun jurnalis tersebut dari judul yang dibuat menyudutkan istri tanpa ada konfirmasi dari pihak terkait dalam tiap-tiap teksnya. Ditemukan pula lead yang tidak sesuai dengan judul. Judul yang dibuat terkesan dipaksakan oleh jurnalis. Beberapa judul dari teks-teks yang dihimpun tersebut menyudutkan istri dalam pemberitaan, sehingga terindikasi tidak balance dan memihak pada pihak-pihak tertentu. Dilihat dari sudut pandang media, Merdeka.com terindikasi menjadi media yang melihat peristiwa pemerkosaan ayah terhadap anak kandungnya sebagai bahan untuk komodifikasi. Hal ini terlihat dari judul berita yang dihimpun terkait alasan-alasan yang dilakukan pelaku berbuat tindakan perkosaan terhadap anak kandungnya. Berita-berita tersebut menonjolkan sensasi lewat diksi dalam judul dan angle yang dipilih. Meskipun jurnalis seorang perempuan, akan tetapi Ia mengambil angle yang merugikan perempuan (istri) bukan melihat dari sisi tersangka yang melakukan pemerkosaan. Hal tersebut mungkin saja terjadi, karena tidak semua perempuan memiliki kesensitifan terhadap perempuan lainnya atau bisa dikatakan tidak semua perempuan bersifat feminin.

\section{DAFTAR PUSTAKA}

Arsam, Romli. 2004. Masalah Perlindungan Anak. AkademikaPresindo,Jakarta. Hartanto, Ahmad. Analisis Wacana Pemberitaan Kekerasan pada Perempuan Di Halaman Patroli HU Solopos Tahun 2007. Skripsi 2009, Universitas Negeri Yogyakarta. http://www.tempo.com/keluarga/61173/, Jumat, 20 Juli 2012. Dekat dengan Ayah Membuat Anak Tumbuh Lebih Bahagia. Diakses melalui Google.com. 22 Mei 2016. http://www.merdeka.com/peristiwa/,Sabtu, 14 Mei 2016. Alasan Konyol Orangtua Tega Memerkosa Anak Kandung. Diakses melalui Google.com. 22 Mei 2016. 
http://www.merdeka.com/peristiwa/, Sabtu, 14 Mei 2016. Kesal Karena Anak Tak Perawan Lagi. Diakses melalui Google.com. 22 Mei 2016.

http://www.merdeka.com/peristiwa/,Sabtu, 14 Mei 2016. Jarang Dilayani Istri. Diakses melalui Google.com. 22 Mei 2016.

http://www.merdeka.com/peristiwa/ Sabtu, 14 Mei 2016. Kalut Istri Tak Kunjung Pulang. Diakses melalui Google.com. 22 Mei 2016.

http://www.merdeka.com/peristiwa/ Sabtu, 14 Mei 2016. Ditolak Berhubungan Badan Sama Istri. Diakses melalui Google.com. 22 Mei 2016.

http://ravik.staff.uns.ac.id/Kamis, 23 Oktober 2009.Pola Hubungan Dalam Keluarga (Suatu Kajian Manajemen Keluarga). Diakses melalui Google.com. 29 Mei 2016.

Kartono,Kartini.1989.Phatologi Sosial.Jakarta: Rajawali.

Kusumaningrat, Hikmat.\&Kusumaningrat, Purnama.2005. Jurnalistik: Teori danPraktek. Bandung: Remaja Rosdakarya.

Lustig, Captain Noel. 1966. Incest: A Family Group Survival Pattern. Archives of General Psychiatry, 14:39.

Manik, Sulaiman Zuhdi. 2002. Penanganan dan Pendampingan AnakKorban Incest.PKPA.

McQuail, Denis, ed. 2004.McQuail's Reader in Mass Communication Theory. London: SAGE Publications Ltd.

Mills,Sara.2007.Diskursus Sebagai SebuahPiranti Analisis dalam IlmuSosial. Jakarta: Qalam.

Renkema, Jan. 2004. Introduction to Discourse Studies. Amsterdam: John Banjamins Publishing Company.

Sadarjoen, Sawitri S. 2005. Konflik Marital. Bandung: Refika Aditama.

Sharma, Arpita. 2012. Portrayal of Women in Mass Media. Media Watch.

Sudibyo. Agus. 2001. Politik Media dan Pertarungan Wacana. Yogyakarta: LkiS

Supratik.1995. Mengenal Perilaku Abnormal. Kanisus: Jakarta.

Van Dijk, A Teun. 1997. Discourse as Structure and Process. London, ThousandOaks, New Delhi: Sage Publications. 